\title{
Article \\ Interplay between Asian Monsoon and Tides Affects the Plume Dispersal of the New Hu-Wei River off the Coast of Midwest Taiwan
}

\author{
Chia-Ying Ho ${ }^{1}$, Tien-Hsi Fang ${ }^{1}$, Cheng-Han $\mathrm{Wu}^{2}$ and Hung-Jen Lee ${ }^{1, *(\mathbb{D})}$ \\ 1 Department of Marine Environmental Informatics, National Taiwan Ocean University, Keelung 20224, Taiwan; \\ 20781001@mail.ntou.edu.tw (C.-Y.H.); thfang@mail.ntou.edu.tw (T.-H.F.) \\ 2 Safety Heath and Environment Center, Formosa Plastics Group, No. 1, Mailiao 638, Taiwan; \\ ahan88@fpg.com.tw \\ * Correspondence: lecgyver@mail.ntou.edu.tw
}

Citation: Ho, C.-Y.; Fang, T.-H.; Wu, C.-H.; Lee, H.-J. Interplay between Asian Monsoon and Tides Affects the Plume Dispersal of the New Hu-Wei River off the Coast of Midwest Taiwan. Water 2022, 14, 152. https:// doi.org/10.3390/w14020152

Academic Editors: Shin-Jye Liang and Miguel Ortega-Sánchez

Received: 25 October 2021

Accepted: 4 January 2022

Published: 7 January 2022

Publisher's Note: MDPI stays neutral with regard to jurisdictional claims in published maps and institutional affiliations.

Copyright: (C) 2022 by the authors. Licensee MDPI, Basel, Switzerland. This article is an open access article distributed under the terms and conditions of the Creative Commons Attribution (CC BY) license (https:// creativecommons.org/licenses/by/ $4.0 /)$.

\begin{abstract}
In the coupled estuary-shelf system, plumes originating from the New Hu-Wei and Choshui rivers, consisting of many terrestrial materials, could contaminate the water of the Mailiao industrial harbor. To determine the contribution of the two rivers to pollution, the interaction between riverforced, tide-generating, and monsoon-driven water motions in and around the Mailiao industrial zone harbor was examined by performing a series of numerical model experiments. We used a threedimensional general circulation model to examine the interplay between Asian monsoon-driven, river-forced, and tide-induced water motions, one of which could primarily affect the plume. The model-derived results for different river discharges revealed that almost all of the ammonium entering the harbor had a slope-positive trend, with oscillations in response to flood-ebb tidal cycles. The ammonium increased with time and flux, except for the $10 \mathrm{~m}^{3} / \mathrm{s}$ flux. Although the river discharge flux exceeded $200 \mathrm{~m}^{3} / \mathrm{s}$, the ammonium entering the harbor was the same as that of the $200 \mathrm{~m}^{3} / \mathrm{s}$ flux; the ammonium concentration did not increase significantly with time after the flux exceeded $200 \mathrm{~m}^{3} / \mathrm{s}$. In addition, irrespective of flood or ebb tidal currents being suppressed by strong Asian monsoons, this mechanism avoided contaminating the water quality of the harbor while northeasterly winds prevailed. By contrast, the southwesterly monsoon drove the geostrophic current northward along the coast; concurrently, the coastal sea level increased to form the surface isobar slope up toward the coast, producing a secondary flow to accelerate geostrophic alongshore currents. The northward geostrophic currents compressed the plumes shoreward, forming a relatively narrow-band plume; the coupling model demonstrated that the southwesterly monsoon-driven current pushed plumes favorably along the west pier into the harbor.
\end{abstract}

Keywords: Mailiao; New Hu-Wei river; Asian monsoon; tidal currents; general circulation model

\section{Introduction}

Along the west coast of Taiwan, a shoal shelf having a width of up to $15 \mathrm{~km}$ extends from north to south for more than hundreds of kilometers. Usually, many types of marine organisms, including fishes, zooplankton, mussels, seaweed, and algae, live in the region. This zone receives considerable terrestrial material containing pollutants from river runoff. The Mailiao industrial zone (MIZ) and Mailiao industrial harbor (MIH) were established in 1991 and 2001, respectively, around the Mailiao area on the coast of Midwest Taiwan, as shown in Figure 1a [1,2], for economic activities (https:/ / www.fpg.com.tw (accessed on 1 July 2021) and http:/ / www.mlharbor.com.tw (accessed on 1 July 2021)). Off the coast of the MIZ, the shelf sea is not barred and directly opens to the Taiwan Strait to its west. A medium-sized river, the Choshui (CS) River, is located to its north, and a small-sized river, locally known as the New Hu-Wei (NHW) river, is situated to its south. Abundant sand and mud from the two rivers are deposited in the region due to the northward and 
southward tidal flow along the coast [3]. Because the tidal current sometimes transports these materials into the $\mathrm{MIH}$, the inside of the harbor and the entrance occasionally require sediment dredging to maintain a fluent waterway [4]. In addition to sand and mud, some terrestrial constituents, such as pollutants, waste water, and nutrients, can be easily transported into the MIH due to its close proximity with the NHW river. Many activities along the NHW river, including rice farming, aquaculture, and pig farms, are conducted downstream or mid-downstream. The drainage of excess feedstuff, fertilizers, and even feces from these farms into the river through small canals results in severe eutrophication or pollution, particularly after heavy rainfall. These pollutants and nutrients are discharged with the flowing river water into the NHW river estuary [5]. In addition, because many Indo-Pacific Humpback Dolphins live and forage in the region, the shelf and its vicinity are becoming an important issue, especially in and around the MIH harbor. Moreover, these creatures are often found to breed their generations inside the harbor. Hence, many environmental groups have requested an environmental impact assessment of the region.
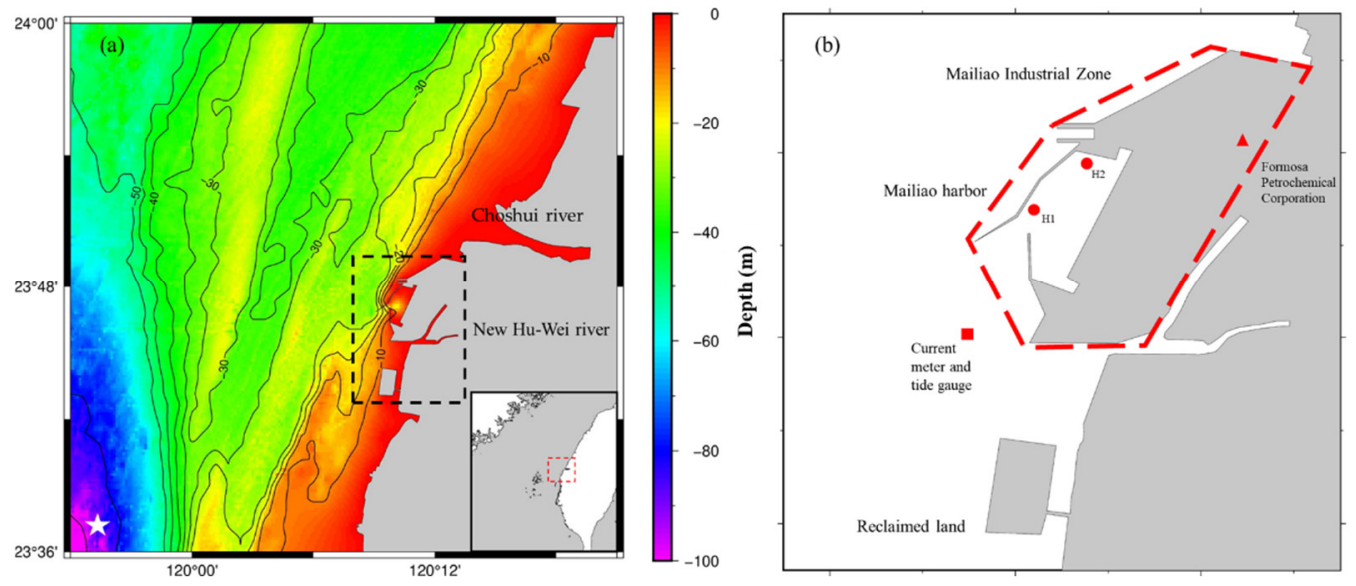

Figure 1. (a) Map; bathymetry (in meters); model domain and the adjacent sea. Conductivity, temperature, and depth (CTD) sampling stations (star); black dashed frame covers the main study area. The large-scale setting at the lower-right corner denotes the study area. (b) Current meter and tide gauge stations (red rectangle); water quality stations (red solid circles). Red dashed frame indicates the Mailiao industrial Zone.

Wastewater discharged from the Formosa Petrochemical Corporation (FPC) into this shelf sea is limited by Taiwan's Environmental Protection Administration regulations (ammonium < $0.3 \mathrm{mg} / \mathrm{L}$; total phosphorus < $0.05 \mathrm{mg} / \mathrm{L}$ ) [6]. The MIZ has 10 wastewater treatment plants, in which the treated wastewater after mixing with the cooling water drains into the nearshore through a diversion dike. In addition to the two pollution sources, the CS River to the farther north of the harbor can be a contributor to pollution. Thus far, no study has examined the source that plays the most crucial role in polluting the estuary-shelf environment. Thus, determining the major contributor to harbor pollutants is essential. However, due to space limitations, the effect of the FPC pollution source on the $\mathrm{MIH}$ seaport is not discussed in the text.

Except for the inside of the harbor, the coupled estuary-shelf system is contaminated by river-forced estuarine plumes, which are mainly modulated by tidal currents, Asian monsoons, and the Earth's rotation [7-9]. The tidal range along the Midwest Taiwan coast is $>4 \mathrm{~m}$, defined as the macrotide, but that at the south of the NHW river estuary is 2-4 $\mathrm{m}$ [10]. Accordingly, the large tidal range generates strong tidal currents in the region. Strong tidal currents flow northward along the shelf coast during flood periods and move to the south during ebb periods. Chao [7] reported that the river plume follows the Kelvin wave characteristics, that is, it hugs the right-hand coast during flood tides. During ebb tides, this tendency disappears due to the lack of the right-hand side coast to hug, leading to the 
plume being deflected to the open sea through tidal advection or wind subject to Ekman transport effects. In addition, water motions in and around the vicinity of the NHW harbor are modulated by East Asian monsoons. The northeasterly monsoon prevails in winter from September to April, usually peaking in December. Nevertheless, the summer monsoon blows from the southwest with a weak intensity and for a short duration, lasting from July to August [11,12]. In a coupled estuary-shelf system, the river-forced plume water usually overlays the seawater to form a stratified water column because of buoyancy force support. Therefore, the plume's fate is easily modulated by Asian monsoons. The significance of the Earth's rotation can be measured using the Kelvin number $(\mathrm{K}=\mathrm{W} / \mathrm{Lr})$ [9], defined as the ratio of the river mouth width $(\mathrm{W})$ to the internal Rossby deformation radius $(\mathrm{Lr} \approx 9132 \mathrm{~m})$. $\mathrm{K}>1$ indicates that the motion is due to a large-scale type, an anticyclonically large bulge plume is formed around the river mouth, and the plume along the right-hand coast extends to the far downstream field [7]. By contrast, $\mathrm{K} \leq 1$ indicates that the motion is due to a smallscale type, the river plume appears seaward around the river mouth, and an anticyclonic plume turning occurs downstream. In addition, the tidal excursion number $(\mathrm{P})$ is used to measure tidal effects. The tidal excursion number $(\mathrm{P}=\mathrm{W} / \mathrm{L})$ is defined as the ratio of the river mouth width $(\mathrm{W})$ divided by the tidal excursion length $(\mathrm{L}) . \mathrm{P}>1$ indicates that the subtidal river plume force is more important than the tidal force. $\mathrm{P} \leq 1$ indicates that tidal currents can dominate the river-forced plume dispersal. Considering that the NHW river's mouth width $(\mathrm{W})$ is approximately $300 \mathrm{~m}$ and taking $v_{0}$ to be approximately $50 \mathrm{~cm} / \mathrm{s}$, the tidal excursion length (L) for semidiurnal tides was calculated using the following equation [8]:

$$
\mathrm{L}=\int_{0}^{T_{s} / 2} v_{0} \sin \left(\frac{2 \pi t}{T_{S}}\right) d t=\frac{T_{s} v_{0}}{\pi} \approx 7116
$$

where $v_{0}$ is the average amplitude of semidiurnal tidal currents and $T_{S}$ is the semidiurnal tide period. Thus, the estimated tidal excursion length (L) is $7116 \mathrm{~m}$, with the ratio $\mathrm{P}=0.042<1$ and the Kelvin number $\mathrm{K}=0.033<1$. Both the Kelvin and tidal excursion numbers were far less than unity, revealing the subtidal river plume to be a small-scale type and implying that tidal currents dominate river-forcing plume characteristics. Theoretically, a dimensionless number is used to measure the surface Ekman drift, that is, the Froude number $(\mathrm{Fe}=\mathrm{Ve} / \mathrm{Ci})$, defined as a ratio of the wind-driven surface flow speed $(\mathrm{Ve})$ to the plume-induced internal phase velocity (Ci). The wind-driven force primarily dominates the river plume fate when $\mathrm{Fe}>>1$; however, the river-forcing plume is unaffected by wind when $\mathrm{Fe}<<1$. Thus, $\mathrm{Fe}=\mathrm{Ve} / \mathrm{Ci}=0.3 / 0.309 \approx 1$ shows that the wind-driven surface drift competes with the river-forced plume motion in this case. The NHW estuary-shelf system estimated from some observed data appears to not be a large-scale type.

\section{Observations}

Two water quality stations with quasi-seasonal, unequal interval time series were deployed inside the harbor to monitor the ammonia concentration to correspond with the EPA environmental regulation. The $\mathrm{H} 1\left(120.161667^{\circ} \mathrm{E}, 23.7883333^{\circ} \mathrm{N}\right)$ water quality station was set up at the inner side of the west pier near the harbor mouth, and $\mathrm{H} 2\left(120.173342^{\circ} \mathrm{E}\right.$, $23.7961222^{\circ} \mathrm{N}$ ) was set up at the inner harbor adjacent to the inlet (Figure 1b). The two unequal interval time series of water quality shown in Figure 2 present ammonia concentration variations from April 2009 to 2016; ammonium, the main product of some farming, increased with time in the long term and demonstrated seasonal variations. The two time series of ammonia concentration variations exhibited the same tendency but were still slightly different in the phase. Among seasonal variations, two concentration peaks that exceeded $20 \mu \mathrm{M}$ were particularly prominent, and they were observed around the summers of 2010 and 2015. If the concentration peaks (i.e., the summer of 2010) in the two series were excluded, their average ammonium concentration was approx. 3-5 $\mu \mathrm{M}$. The wet season in Midsouth Taiwan is during summer, with frequent heavy rainfall. After heavy rainfall, a large mass of freshwater with pollutants is discharged into the estuary-shelf region. Subsequently, these substances are transported into the harbor with tidal currents. 
Except for the two peaks of high ammonium concentrations in summer, the other values remain stationary, with an average value of $4 \mu \mathrm{M}$. Thus, to some extent, the ammonia concentration in the harbor mostly depends on the river runoff. In addition, to investigate the effect of the NHW river plume, water quality was measured once a quarter at 14 stations in and around the river's estuary by using fishery boats (Figure 3a). Three water quality stations were designed only to sample the downstream river in which the concentration of ammonia was usually higher than those of other stations, except during heavy rainfall, particularly at X1, X2, and X3 stations. Stations confined by a black dashed frame indicate sampling positions at the Choshui (CS) estuary, and stations confined by two red dashed frames indicate sampling positions at the estuary and estuary offshore, respectively. From water sampling performed once a quarter for more than two years, the average ammonium concentrations off the coasts of the NHW and CS rivers were 10 and $4.5 \mu \mathrm{M}$, respectively.

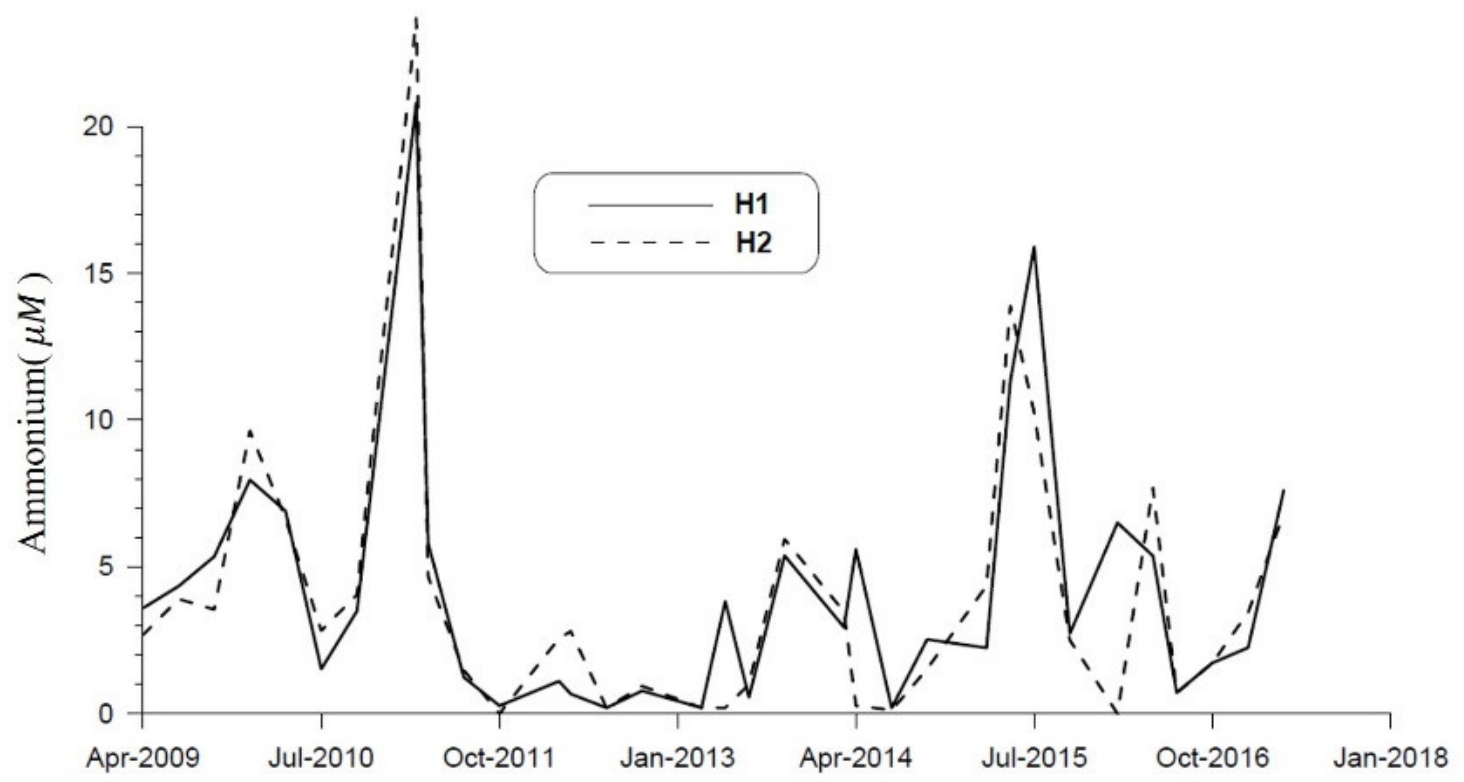

Figure 2. Two unequal interval time series of ammonium at stations H1 (solid line) and H2 (dashed line) inside the harbor were sampled from 2009 to 2016 . The time-series variations show that the $\mathrm{H} 2$ ammonium concentration was generally consistent that of $\mathrm{H} 1$.

Off the NHW estuary, the ammonium concentrations at $\mathrm{X} 12, \mathrm{X} 13$, and $\mathrm{X} 14$ stations were relatively low (an average value of $1 \mu \mathrm{M}$; Figure $3 \mathrm{~b}$ ). This value may be considered a background value around the MIZ region. As shown by red dots in Figure 3b, a high ammonium concentration of $>140 \mu \mathrm{M}$ at $\mathrm{X} 1$ and $\mathrm{X} 2$ stations appeared after heavy rainfall on 14 August 2020. Furthermore, as depicted in Figure 4a, the ammonium concentration field formed prominent fronts with the eastward direction in the estuary among the harbor mouth, offshore stations (X12, X13, and X14), and the reclaimed land caused by the high to low concentrations during the general case. As shown in Figure 4b, on 14 August 2020 , the ammonium concentration distributed in the region, that is, that around station $\mathrm{X} 10$, unexpectedly reached $30 \mu \mathrm{M}$, indicating that significant quantities of pollutants and ammonium follow the river water discharge into the NHW river estuary during heavy rainfall. 

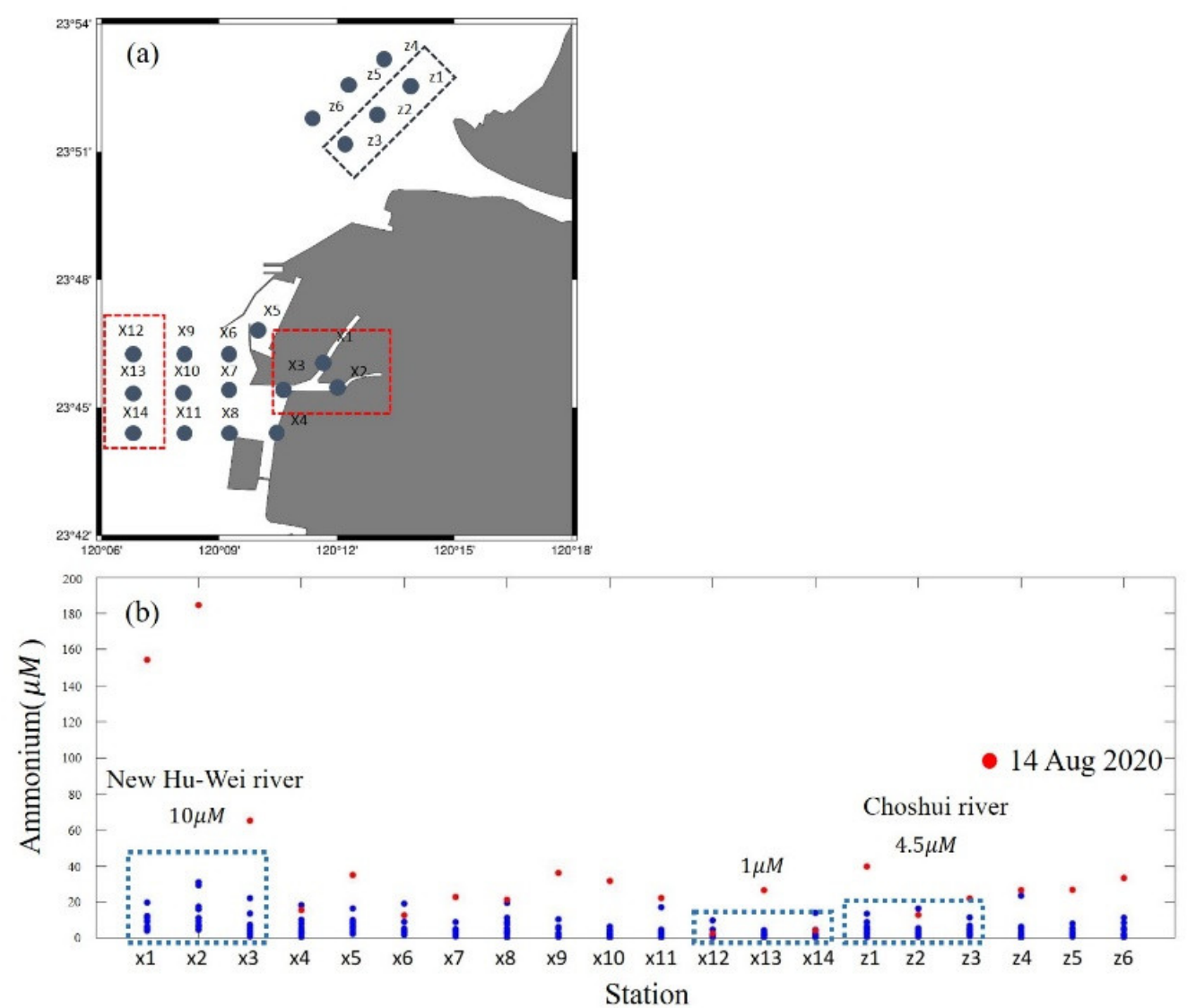

Figure 3. (a) Water quality was sampled at 14 stations (x1-x14) and 6 stations (z1-z6) around and offshore from the river's estuary. (b) Blue and red dots indicate the ammonium concentration revealed by water quality sampling stations for the general case and for a special case on 14 August 2020, respectively. Blue dashed frames cover three stations and denote the average ammonium concentration of three stations.
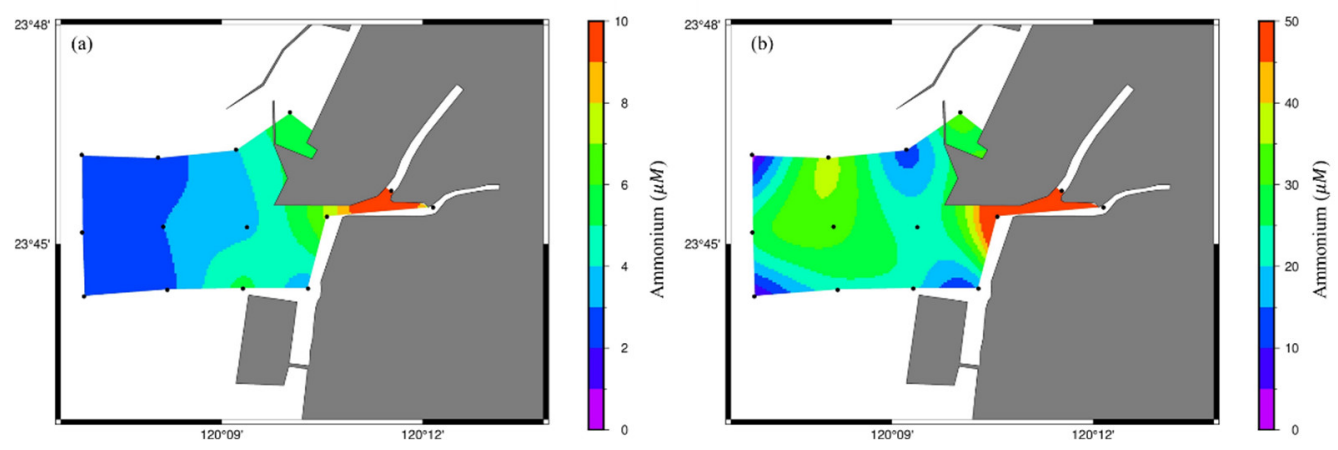

Figure 4. (a) Observed ammonium-concentration field for the general case. (b) Observed high ammonium-concentration field for a special case measured on 14 August 2020 after heavy rainfall. Note that the color bars show different values in the two diagrams.

Current meter and tide gauge stations $\left(120.1524^{\circ} \mathrm{E}, 23.76053^{\circ} \mathrm{N}\right)$ were deployed at the front of the harbor mouth to collect local tidal currents and sea-level variations at 10 min intervals from May to December of 2016. As shown in Figure 5a, the longterm sea-level variations approached the range of the so-called macrotide $(>3.6 \mathrm{~m})$; the close-up diagram of the sea level indicates that it is a semidiurnal type region (Figure $5 b$ ). Figure $5 c$ displays the Fourier power spectrum derived from sea-level statistical analysis; 
semidiurnal tides were considerably greater than diurnal ones. Furthermore, the form number, $\mathrm{F}=\left(\mathrm{K}_{1}+\mathrm{O}_{1}\right) /\left(\mathrm{M}_{2}+\mathrm{S}_{2}\right)=0.202$, was estimated at the tide gauge. Accordingly, the region was considered to be a semidiurnal type because the form number $(0.202)$ was far less than 1.25 [4]. The local flow fields predominantly indicated that tidal currents with fortnightly amplitude modulation (Figure 6a) flowed along the coast northward and southward during flood tides and ebb tides, respectively. The close up of the current speed shown in Figure $6 \mathrm{~b}$ exhibits that the northward velocity component may reach the speed of approximately $100 \mathrm{~cm} / \mathrm{s}$.
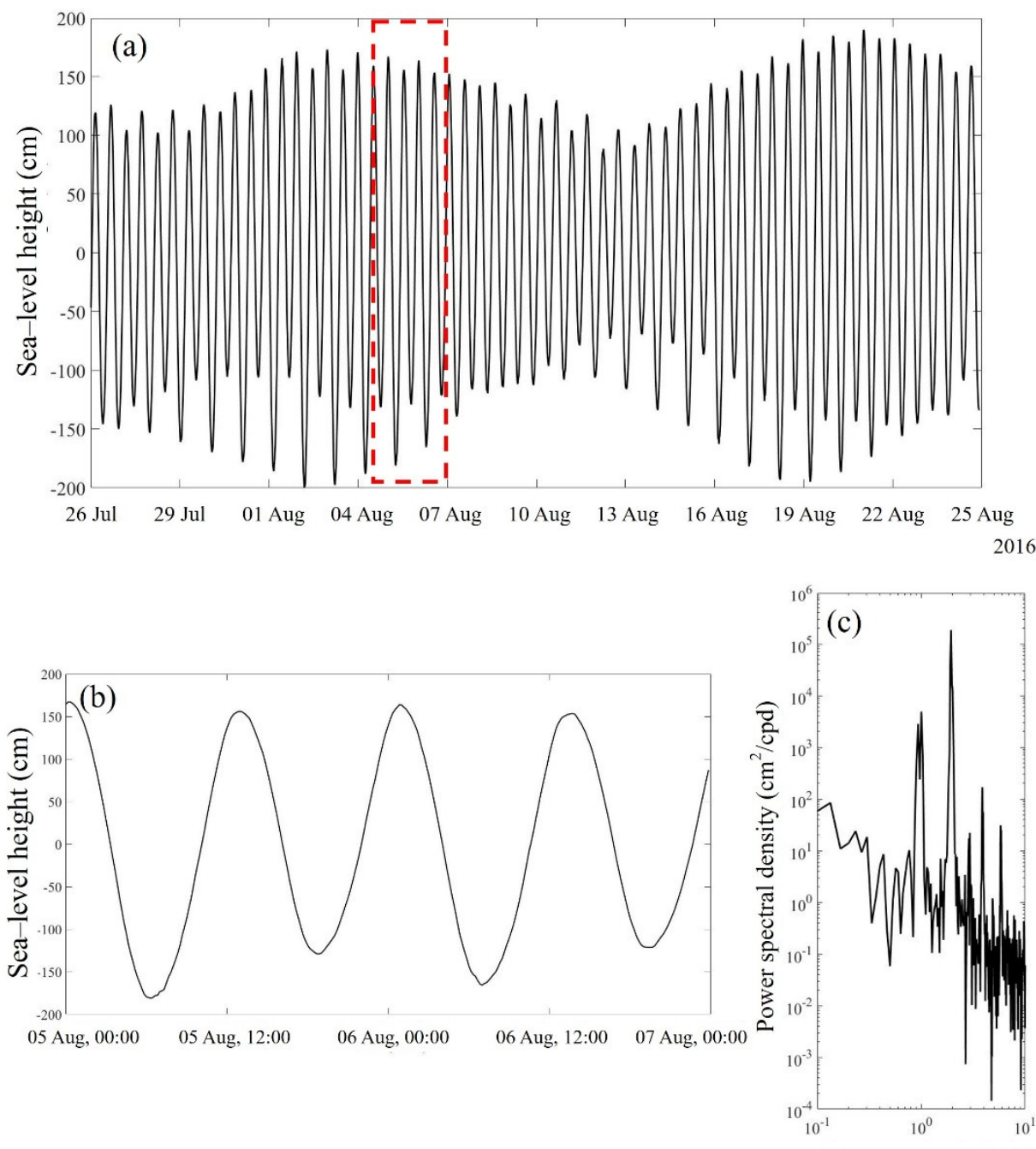

Frequency (cycle/day)

Figure 5. (a) Sea-level time series at the tide gauge station shows the extensive tide range in the region. (b) The close-up of sea-level time series (red dashed frame) shows the extensive tidal range in the region. (c) Power spectra of the sea level at tide gauge station. Frequency is presented using the unit of cycles per day. 


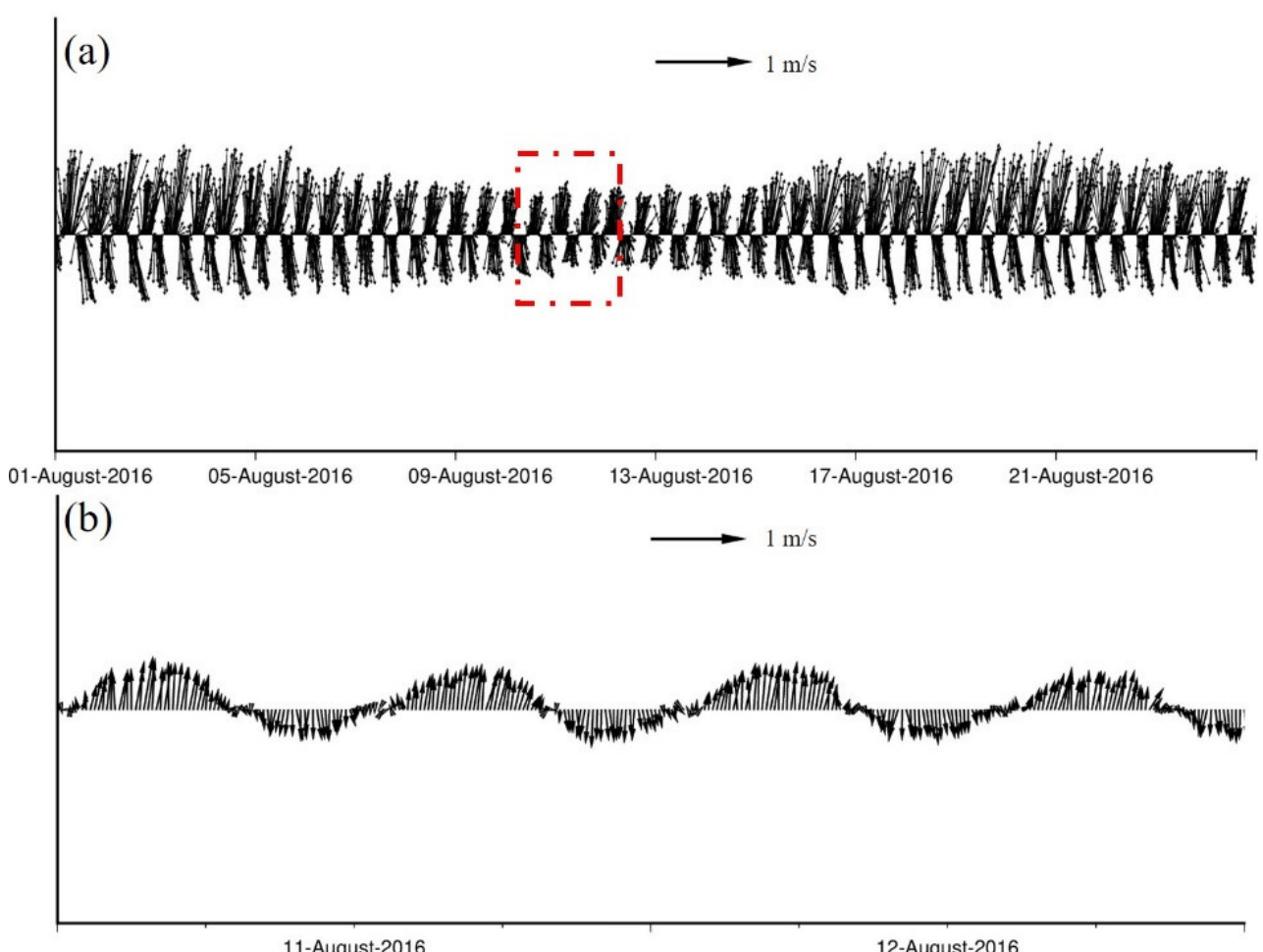

Figure 6. Local flow fields indicate that tidal currents predominantly vary with fortnightly amplitude modulation (a) approximately flowing northward during flood tides and southward during ebb tides. (b) The close-up of the current speed (marked with red dashed line in (a)) exhibits that the semidiurnal tide dominates in the region.

Except for during heavy rainfall, discharges estimated from the catchment areas of CS $\left(3156.9 \mathrm{~km}^{2}\right)$ and NHW $\left(109.3 \mathrm{~km}^{2}\right)$ rivers usually have a typical value of approximately $20 \mathrm{~m}^{3} / \mathrm{s}$ (Figure 7a) and $10 \mathrm{~m}^{3} / \mathrm{s}$ (Figure $7 \mathrm{~b}$ ), respectively. In Midsouth Taiwan, the wet season is usually associated with heavy rainfall in summer, peaking in duration from June to October [10]. A large amount of fresh water from these catchment areas runs off through the two rivers and discharges into the nearshore coast, particularly during a typhoon (Figure 7).

The discharge flux of the two rivers is negligible in the non-wet season. The average discharge flux of each river was concurrently imposed on the model as initial conditions. Regarding East Asian monsoons, Figure 8 presents wind rose diagrams derived from statistical wind data (https:/ / cbw.gov.tw (accessed on 23 February 2021)). In the region and its vicinity, the wind prior to June prevailed in the northeast monsoon $(5.9 \mathrm{~m} / \mathrm{s}$ on average), but the northeast monsoon ended in June. The southwest monsoon $(4.4 \mathrm{~m} / \mathrm{s}$ on average) began to blow from the southwest and, being much weaker and shorter in duration, it lasted from June to August $[3,11,12]$. 


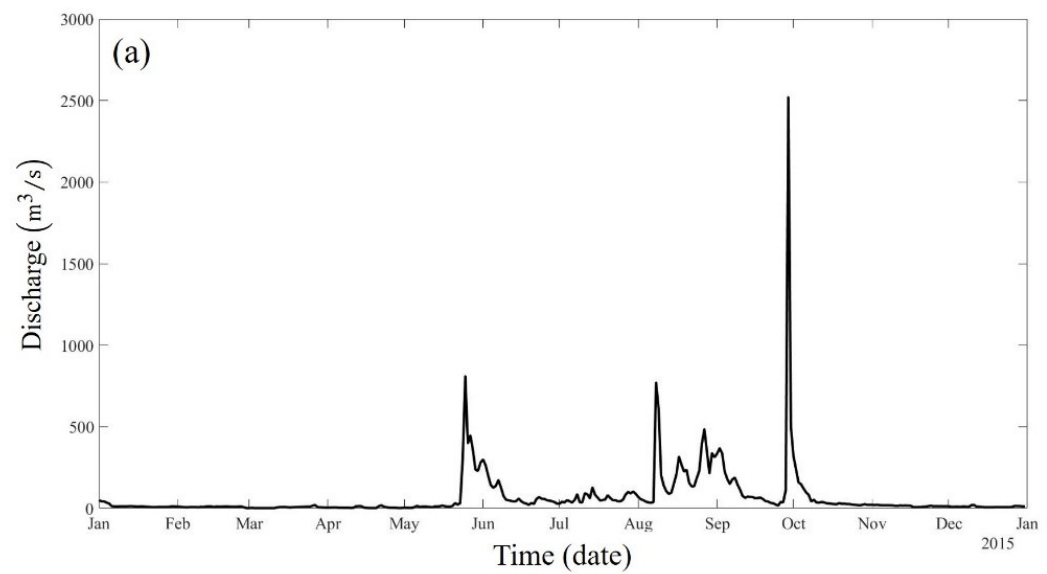

(b)

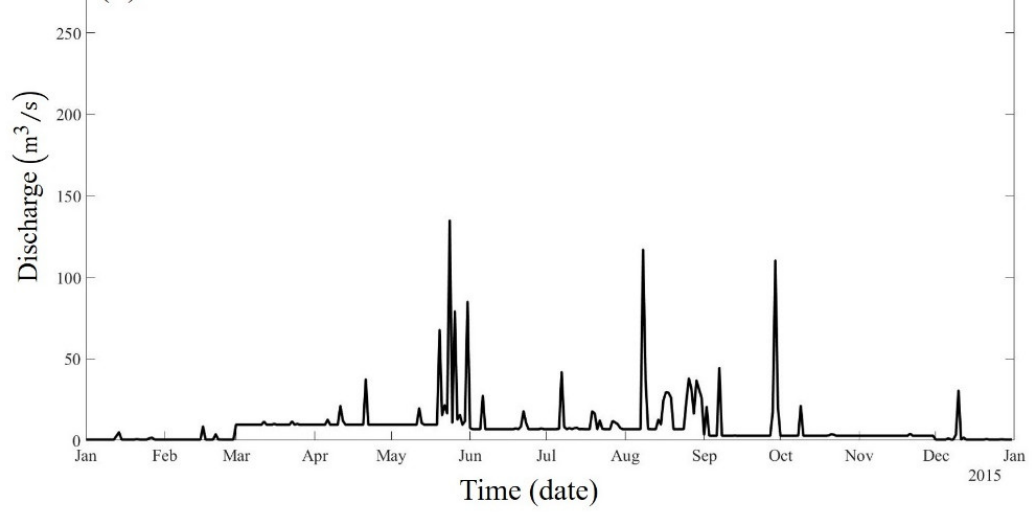

Figure 7. Time-series discharges estimated from the two catchment areas of CS (upper panel; $3156.9 \mathrm{~km}^{2}$ ) and NHW (bottom panel; $109.3 \mathrm{~km}^{2}$ ) rivers presented an average value of approximately $20 \mathrm{~m}^{3} / \mathrm{s}$ in (a) and $10 \mathrm{~m}^{3} / \mathrm{s}$ in (b) in 2015 , respectively.

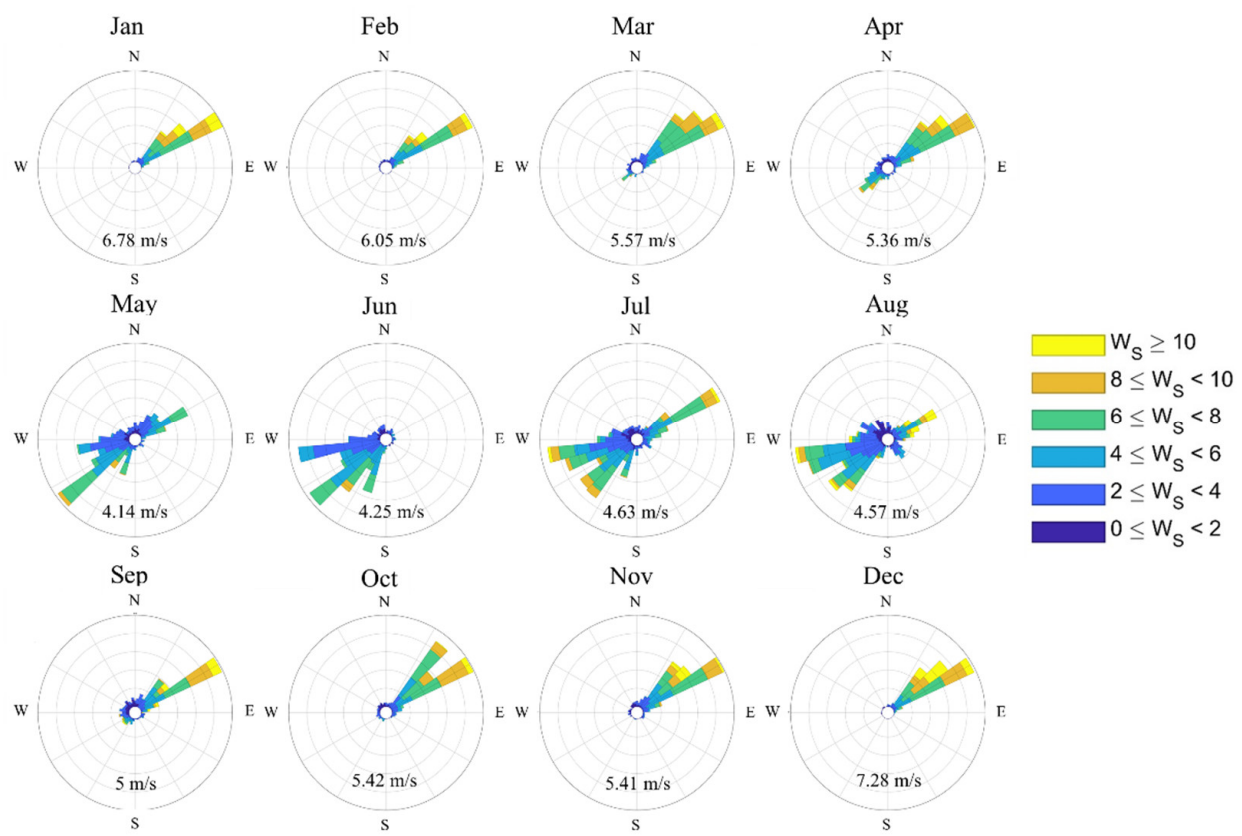

Figure 8. Monthly wind rose diagrams of East Asian monsoons derived from statistical wind data (https:/ / cbw.gov.tw (accessed on 23 February 2021)) are exhibited from January to December in 2015. 


\section{Model Formulation}

Because pollutants, such as ammonium, in the Mailiao harbor can have many sources, the major pollutant source must be identified. To determine the pollutant source, we performed a series of numerical experiments to distinguish the sources' fractional contributions under different conditions. A three-dimensional general circulation model (GCM) initially developed by Semtner [13] was employed in the present study. Similar to the general circulation model of Lee et al. $[4,14,15]$, the numerical code was based on the Bryan-Cox model except for the addition of a free surface for adapting to sea-level tidal fluctuations [16]. Under Boussinesq and hydrostatic approximations, the numerical model solves threedimensional momentum, temperature, salinity, and continuity equations. The model has been successfully used in large-scale studies [11,15,17] and small-scale studies, such as the circulation studies conducted in Nanwan Bay, lagoon, and Yin-Yang Bay [4,8,9,14]. More details regarding the model information are provided by Chao et al. [17]. The numerical model domain for the present work ranged from $119.9^{\circ} \mathrm{E}$ to $120.4^{\circ} \mathrm{E}$ in longitude and from $23.6^{\circ} \mathrm{N}$ to $24.0^{\circ} \mathrm{N}$ in latitude, with a horizontal grid resolution of $100 \mathrm{~m}$, that is, $\Delta x=\Delta y=100 \mathrm{~m}$. There were 20 levels in the vertical direction, and their layer thickness gradually increased with the increasing depth. The thickness of the top six layers was set to $2 \mathrm{~m}$ and that of the seventh layer was $3 \mathrm{~m}$. The thickness between the 8 th and 14th layers was set to $5 \mathrm{~m}$. Below the 14th layer, each layer was $10 \mathrm{~m}$ thick. However, the resolutions in horizontal and vertical directions should be suitable for the present study. In the model interior, the coefficient of the horizontal eddy viscosity was $90,000 \mathrm{~cm}^{2} / \mathrm{s}$ for momentum, and the horizontal mixing coefficient was $18,000 \mathrm{~cm}^{2} / \mathrm{s}$ for temperature and salinity. To determine vertical viscosity and diffusivity coefficients, these values were automatically calculated from the Richardson number referred to in the formulae of Pacanowski and Philander [18]. The temperature and salinity profiles derived from the R/V Researcher Vessel No. 3 (Figure 9) were used as the model's initial conditions.

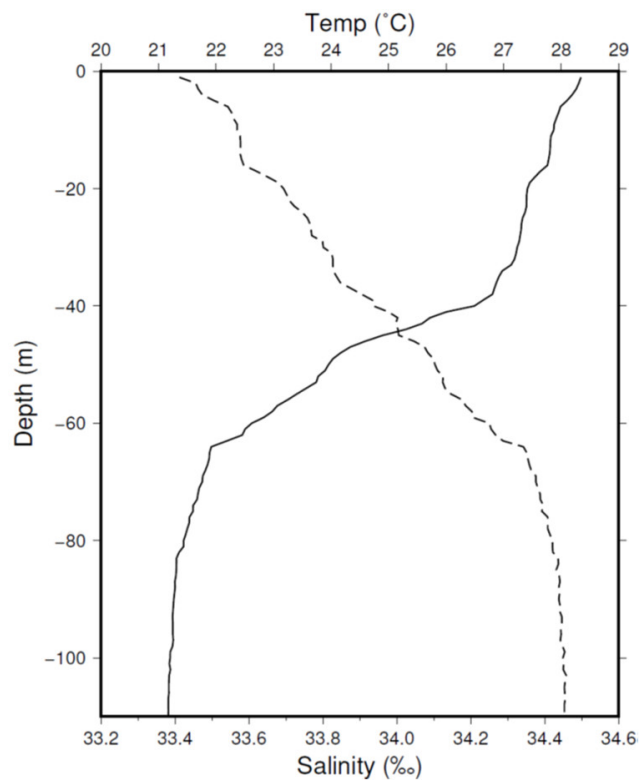

Figure 9. Observed temperature (solid line) and salinity (dashed line) profiles derived from the CTD sampling casts at $119.8511^{\circ} \mathrm{E}, 23.6373^{\circ} \mathrm{N}$ of the R/V Researcher Vessel No. 3 were imposed as the model's initial conditions. The station location is denoted by a star mark in Figure 1a.

Figure 9 shows a $40 \mathrm{~m}$ thick mixing layer below the sea surface and a $20 \mathrm{~m}$ thick thermocline between a depth of 40 and $60 \mathrm{~m}$ in the water column; salinity usually smoothly increases with the increasing depth from the sea surface. To maintain the model temperature and salinity field while the model is being run, the model temperature and salinity variables are softly nudged by a restoring force toward the observed data [19]. In addition, 
the model's solid boundaries are impenetrable, impermeable, and no-slip except at the bottom, where the quadratic stress law with a drag coefficient fixed at 0.0035 determines hydrodynamic resistance. At the bottom interface, the quadratic stress law is expressed as below [7]:

$$
\left(\tau_{b}^{x}, \tau_{b}^{y}\right)=v \frac{\partial}{\partial z}(u, v)=b\left(u^{2}+v^{2}\right)^{1 / 2}(u, v)
$$

where $\tau_{b}^{x}$ and $\tau_{b}^{y}$ represent the bottom stress in $x$ and $y$ directions, respectively; $b$ is a drag coefficient fixed at $0.035 ; v$ is the coefficient of vertical eddy viscosity; and $u$ and $v$ represent the model velocity in $x$ and $y$ directions, respectively. To prevent heat and salt escape, temperature and salinity fluxes through the model sea surface are set to zero. On the surface boundary,

$$
\frac{\partial}{\partial z}(u, v, T, S)=0
$$

where $T$ and $S$ represent the temperature and salinity, respectively. The northern, southern, and western boundaries are open except for the landmass on the right-hand side. The depth-averaged velocity $\left(u_{n}\right)$ normal to the open boundary is prescribed on the southern and northern open boundaries. However, the velocity tangential to the open boundary is set to zero on the two open boundaries. On the western open boundary, the velocity normal to the open boundary is specified to be zero, but the tangential velocity can be calculated as follows:

$$
u=\frac{\partial v}{\partial n}=0
$$

where the unit vector $\mathrm{n}$ is normal to the western boundary. In Equation (5), the radiation boundary condition is used to adapt the temperature and salinity fluctuations on all open boundaries [7].

$$
\frac{\partial(T, S)}{\partial \mathrm{t}}+u_{n} \frac{\partial(T, S)}{\partial n}=0
$$

where $n$ is normal to the open boundary and $u_{n}$ is the velocity component normal to the open boundary; on the western boundary, it is similar to a solid boundary but allows it to slip freely. In the study region, tidal currents involving diurnal and semidiurnal tide constituents dominate water motions (Figures 5 and 6). During flood tides, tidal currents along the right-bound coast flow northward into the southern open boundary as an inflow to the model and as an outflow in the northern open boundary. By contrast, ebb currents move southward from the northern open boundary into the model interior as an inflow of the model and an outflow in the southern open boundary. Subsequently, the model was driven by the depth-averaged velocity derived from a tide-generating force. A tide gauge $\left(120.1524^{\circ} \mathrm{E}, 23.76053^{\circ} \mathrm{N}\right)$ was deployed at the mouth of the MIH to collect sea-level variations. The collected sea levels were decomposed into a few tidal constituents using a tidal height prediction program reported by Foreman [20]. Subsequently, depending on the magnitude of energy to sort the top six tide constituents, as shown in Table 1 , these constituents (K1, O1, Q1, M2, S2, and N2) were added together to form a sea-level equation $[4,15]$.

$$
\xi(t)=\sum_{i=1}^{6} f_{i} \varsigma_{i} \cos \left(w_{i} t-\theta_{i}\right)
$$

where $t$ is the model barotropic marching time, $\theta_{i}$ is the phase lag, $f_{i}$ is the nodal factor (here assumed to be unity), $\varsigma_{i}$ is the amplitude, and $w_{i}$ is the angular frequency of each tidal constituent relative to some defined time zero. According to Pugh's [21] formula, the tidal current velocity acting as the model driving force was transferred from the sea-level equation into the corresponding tidal currents, as below [15,21]:

$$
\mathrm{V}=\sqrt{g / D} \sum_{i=1}^{6} f_{i} \zeta_{i} \cos \left(w_{i} t-\theta_{i}\right)
$$


where $D$ is the undisturbed water depth at open boundaries and $g$ is the gravitational acceleration. Although the tide gauge used for collecting data regarding sea-level variations should be set up near the northern and southern open boundary coast, this was not feasible because of geology-related limitations. Therefore, to simulate flood and ebb tides, the group velocity of shallow-water propagating wave theory was adopted to estimate two-phase lags between the tide gauge station and the northern open boundary, and between the tide gauge station and the southern open boundary. The time lag, which was estimated roughly to be $1000 \mathrm{~s}$, was adopted in the model as the tidal wave propagates from the southern to northern open boundaries.

Table 1. Amplitudes (in meters) and phase lag (in degree) of dominant tidal harmonic constituents at the tide gauge station in Figure 1b. Phase lag with reference to 3 September 2016, 00:00 GMT.

\begin{tabular}{ccc}
\hline & \multicolumn{2}{c}{ Tide Gauge Station } \\
\cline { 2 - 3 } Tides & Amplitude & Phase Lag \\
\hline Q1 & 0.0311 & 291.60 \\
O1 & 0.1526 & 114.83 \\
K1 & 0.1972 & 282.93 \\
N2 & 0.2509 & 27.37 \\
M2 & 1.3874 & 211.57 \\
S2 & 0.3432 & 359.72 \\
\hline
\end{tabular}

The volumetric discharges of CS and NHW rivers were set, at each upstream boundary, approximately four grids up the river mouth. The passive tracer as ammonium concentration was released at the same position at each upstream boundary. The flux magnitude of each river depends on the case study; however, two-river fluxes are usually specified at $10 \mathrm{~m}^{3} / \mathrm{s}$ except in special circumstances. An inlet in the harbor draws seawater for cooling to maintain the FPC manufactory's normal operation; after cooling, warm seawater discharges into the north close-in coast of the harbor from the outlet. According to reports, the quantity of seawater pumped for cooling is approximately 13 million tons per day; this system is also considered to operate in our model. The governing equation discretization for the time matching procedure is coded using the typical mode-splitting technique, separating it into external and internal modes [14,22]. The external and internal time steps for the model run are 0.2 and $12 \mathrm{~s}$, respectively. The model is spun up from a motionless ocean, and the model under such initial and boundary conditions works steadily; cyclical stationary for momentum was reached after 3 days. The model was run for approximately 15 days; the 15th day's model results are discussed below.

\section{Model Results}

\subsection{Plume of the Two Rivers Affects the Water Quality of the MIH}

Before performing complex numerical experiments, we used the $3 \mathrm{D}$ general circulation model with a simple setup to understand the basic features of the region. The model was set to the conditions of no winds, fixed discharge flux at 10 and $10 \mathrm{~m}^{3} / \mathrm{s}$ for both CS and NHW rivers, respectively, and release of ammonium (hereafter, 4.5 and $10 \mu \mathrm{M}$ for CS and NHW rivers, respectively, with $1 \mu \mathrm{M}$ for background value) in downstream boundaries. The model initially considered a motionless ocean and was run day-to-day for 15 days of integration. The model run worked well and was stable, and the 15th day's results are used in the discussion. In addition, the oxidation of ammonium to nitrate through the microbial process in the enriched environment requires approximately 10 days. Thus, ammonium can act as a tracer in the model because the process has a reasonably long oxidization time.

The model results revealed that offshore currents with a velocity of approximately 80-100 cm/s had a northward flow during flood tides. Moreover, in the shadow zone between the harbor and reclaimed land, tidal currents formed a weakening anticyclonic eddy (Figure 10a). In contrast to flooding tides, tidal current $(100 \mathrm{~cm} / \mathrm{s})$ along the west coast of the MIZ had a southward flow during the ebb tide and formed a weak southward 
flow field in the shadow zone while carrying the NHW water to the south (Figure 10b). In addition, irrespective of the tide status, few weak currents sluggishly flowed into the harbor (Figure 10). A modeled velocity equivalent to the location of the current meter station agreed well with the observed current for verification, although the model flood velocity in each cycle slightly differed from the observed flood current data after reaching a peak (Figure 11).
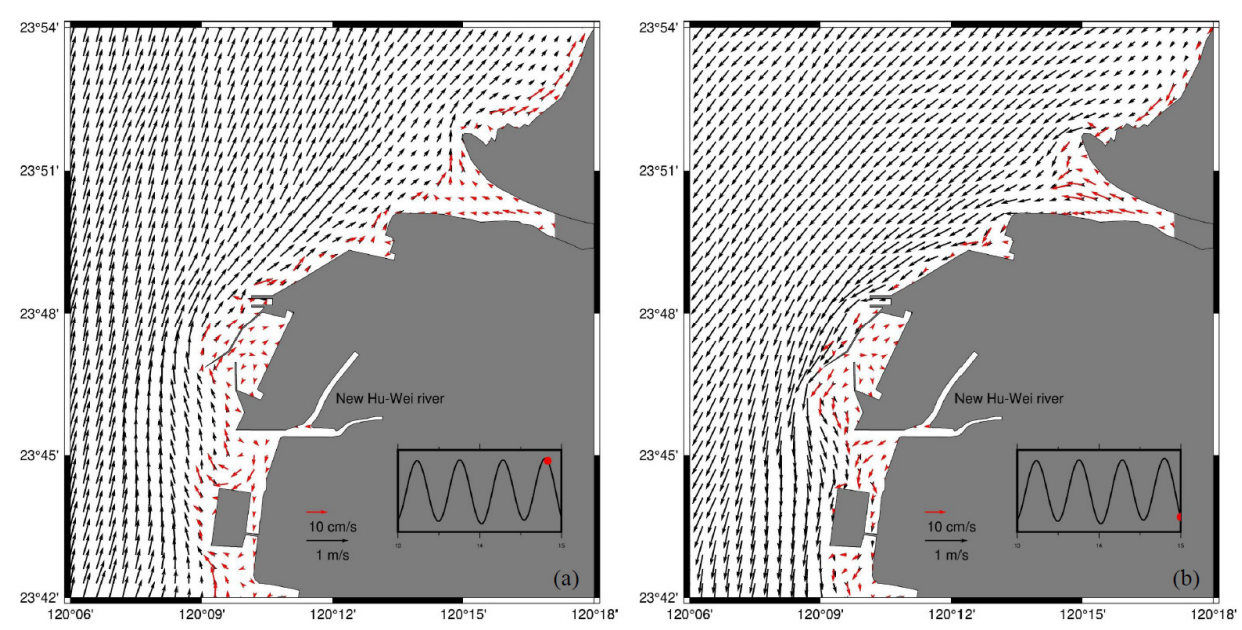

Figure 10. (a) Model results show that alongshore currents flow northward at approximately 80$100 \mathrm{~cm} / \mathrm{s}$ during flood tides, with an anticyclonically weak recirculation (red arrows) in the NHW estuary. (b) The tidal current $(100 \mathrm{~cm} / \mathrm{s})$ along the west coast of the Mailiao industrial zone flows southward during ebb tides with weak southward currents in the NHW estuary. Note that the black and red arrows have different scale bars.

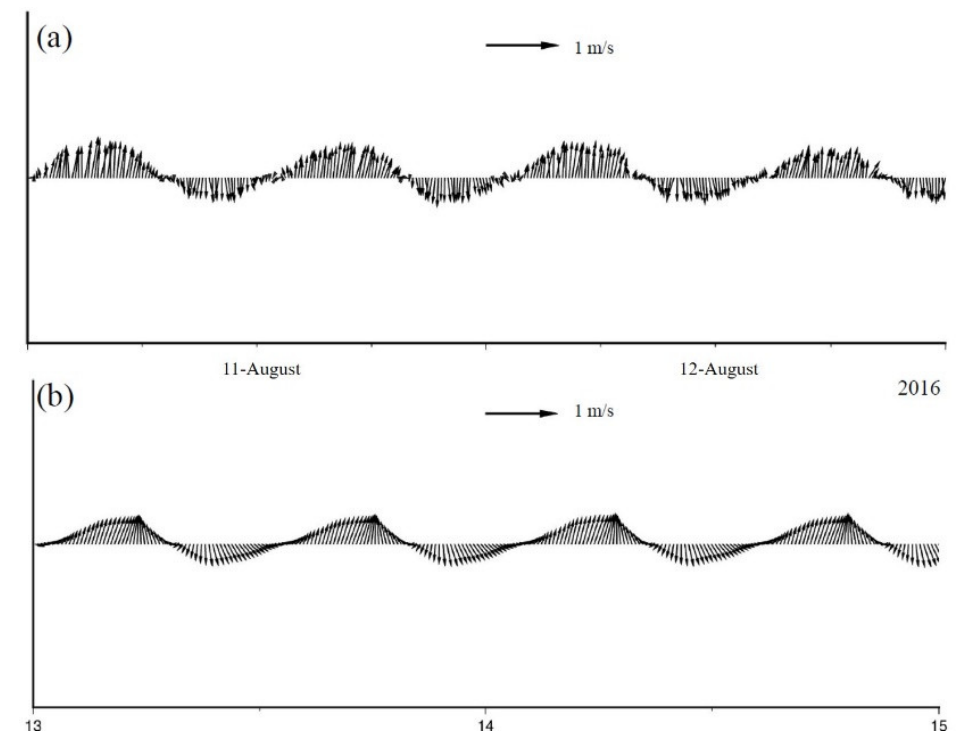

Figure 11. (a) The observed current flow on 11-12 August 2016 at the ADCP current station (b) The modeled velocity equivalent to the current meter location agrees well with the observed current.

To determine the contribution fraction of the two river systems, the tracer was released only for one river each time in the running model for the case. Figure 12 shows the model ammonium concentration fields with (Figure 12a) and without (Figure 12b) the release of the CS river. The total amount of ammonium entering the harbor from the two river systems was $1.63 \mu \mathrm{M}$ on average, although the amount of ammonium entering varied with the flood-ebb and fortnightly spring-neap cycles. The model result indicated that 
the ammonium concentration of the CS river carried by tidal currents entering the harbor was less than $2.5 \%$ of that of the NHW river, as shown in Figure 13 . Therefore, the CS river's contribution level of contaminating the water quality of the MIZ harbor is minor. Accordingly, hereafter we did not emphasize the effect of the CS river on the harbor, though we still maintained its discharge flux during the model run for performing a series of experiments.

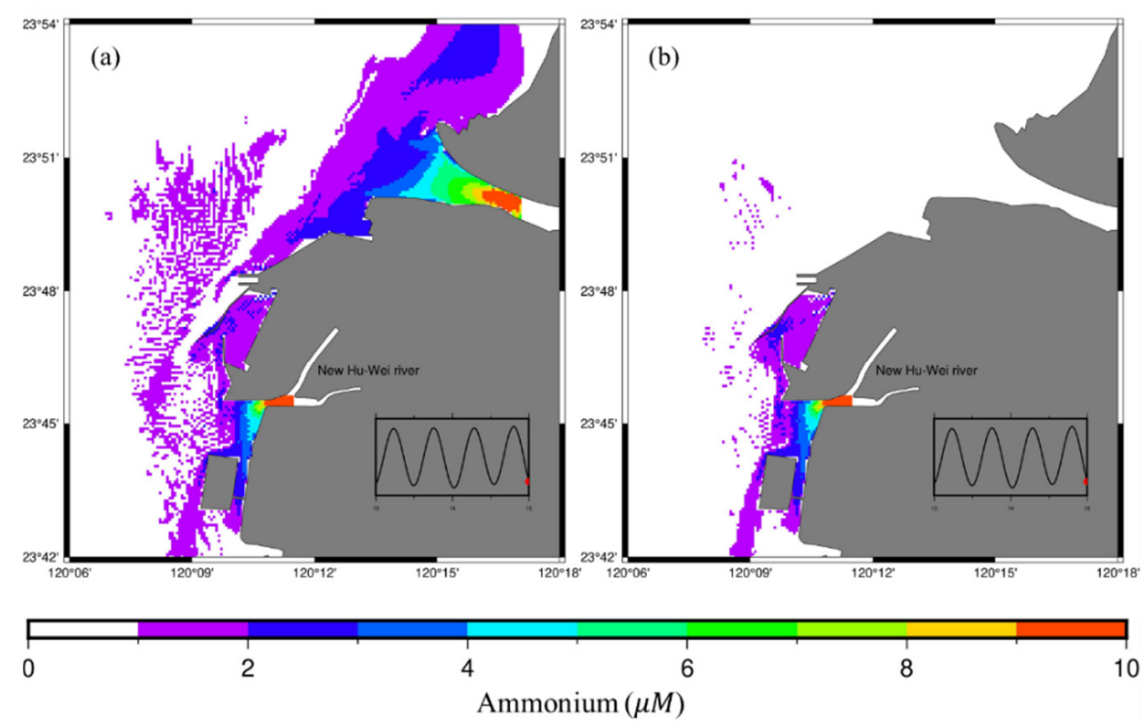

Figure 12. During the ebb, low slack water in the ammonium concentration (a) with the CS river and (b) without the CS river. A small insert at the lower-right corner indicates the tidal phase.

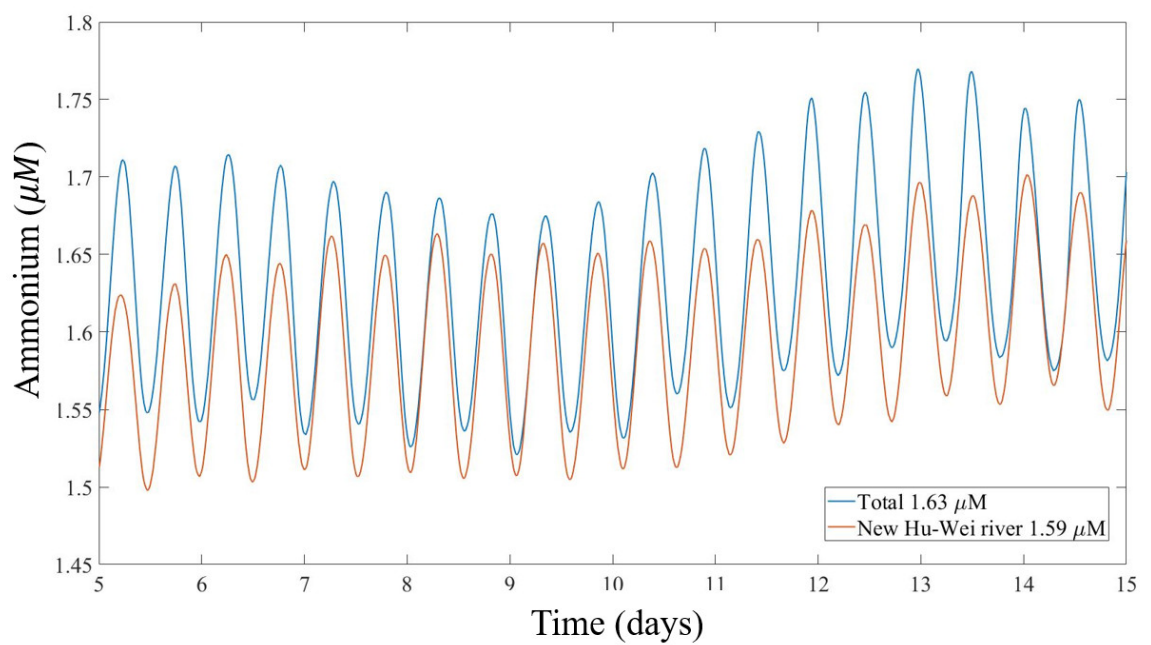

Figure 13. The blue line indicates that the model time series of the total ammonium (1.63 on average) originating from the two river systems varies in the harbor. The red line indicates that the model time series of the NHW ammonium (1.59 on average) only originating from the NHW river varies in the harbor. The two time-series fluctuations from the 3rd to 15th day respond to the flood-ebb and fortnightly spring-neap cycles.

\subsection{No Wind}

Figure 14 depicts the model ammonium-concentration fields under the no wind condition in this study region during the flood and ebb tides. Although the flood tide prevailed at the high slack water, the ammonium tracer originating from the CS river appeared to be pushed back northward (Figure 14a). Moreover, the relatively high ammonium concentration of the CS river mouth was brought to the north along the right-hand coast. 
In the region between the NHW river mouth and inshore coast, the ammonium formed a seaward concentration front from high to low. Concurrently, an ammonium filament (approximately $3 \mu \mathrm{M}$ ) along the south pier extended to the harbor mouth, implying that a part of the ammonium from the NHW estuary began entering the harbor at this time. The ammonium concentration was considerably higher from the prominent tracer front to the inland river than the zone to the east of the front. When viewed seaward from the coast of the MIZ, the ammonium concentration was substantially low, almost approaching the background value in the offshore open sea during the prevailing flood tide; however, the river plume connected with the tracer front formed a narrow band of the ammonium filament flowing northward along the south pier to the harbor mouth (Figure 14a). Some patches broken from the filament entered the harbor and the inner harbor at the low slack water (Figure 14b). To the south of the NHW river mouth, a relatively low concentration tracer moved southward along the coast through the channel between the coast of the MIZ and the reclaimed land but immediately disappeared as it left the channel during ebb tides (Figure 14b). The front to its east was a low concentration region; we believe it was eroded by strong tidal currents (i.e., dilution by advection of the strong tidal currents).

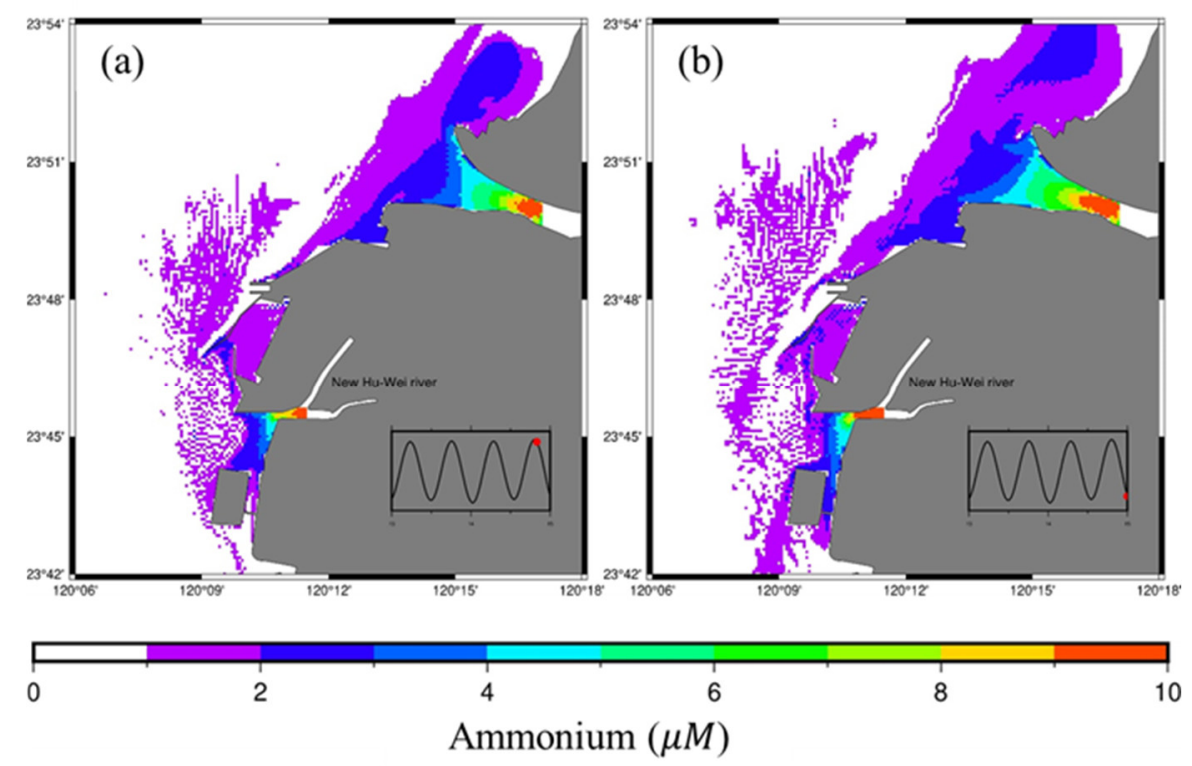

Figure 14. The ammonium-concentration fields of the instantaneously model output during the (a) high slack water and (b) low slack water. A small insert at the lower-right corner indicates the tidal phase.

\subsection{Southwesterly Winds}

Although prevailing winds were southeasterly, they always dominated the river plume behavior, irrespective of flood or ebb tides. Figure 15a displays the ammonium tracer originating from the NHW river being pushed northward by the wind stress of Asian summer monsoons and entering the harbor along the west pier during flood tides, of which the partial tracer reached the inlet. During the ebb, the ammonium tracer distribution appeared to be similar to that of the flood except that in the river mouth; part of the tracer diffused southward to adhere to the north and west sides of the reclaimed land (Figure 15b). Both the ammonium tracers appeared to approach the background value west of the south jetty. 


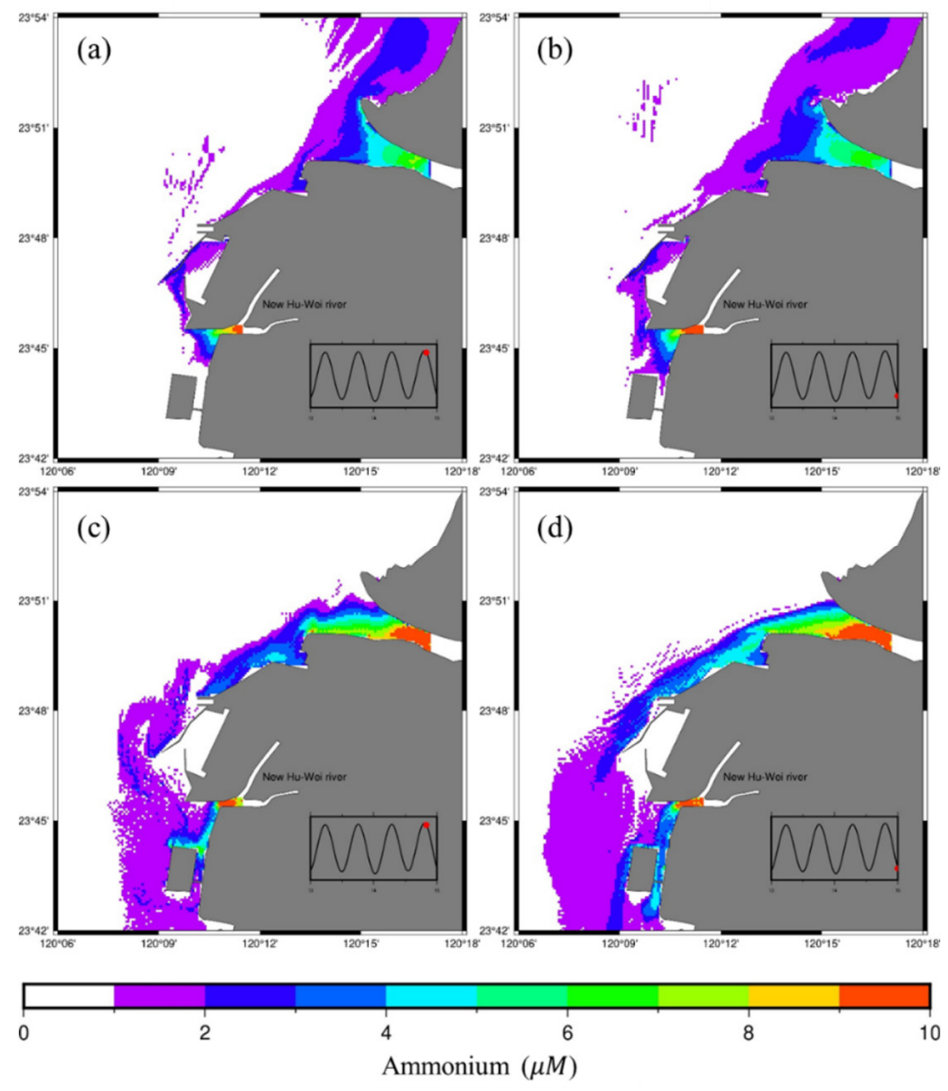

Figure 15. The color image represents the distribution of the model ammoni-um-concentration fields, while southwest winds are prevalent during the (a) high slack water and (b) low slack water, and while northeast winds are prevalent during the (c) high slack water and (d) low slack water. The inserts at the lower-right corner indicate the tidal phase.

\subsection{Northeasterly Winds}

Figure $15 \mathrm{c}, \mathrm{d}$ shows the ammonium tracer distribution under the effect of northeasterly monsoons during flood and ebb tides, respectively. When the northeasterly winds were prevalent, the ammonium tracer, including the CS and NHW river tracers, flowed southward along the coast and directly passed by the harbor mouth. The northeasterly wind-driven forces pushed the surface layer water flowing southward during flood and ebb periods; however, the plume feature in and around the NHW estuary showed a slight difference. By comparison, the plume tracer originating from the NHW river appeared to show alongshore dispersal more toward the south around the reclaimed land during the ebb period. The ammonium tracer did not enter the harbor through its mouth. Moreover, its value was the same as the background value of the inside harbor. These findings indicated that the water quality in winter is more favorable than that in summer.

\subsection{Relationship between Harbor Pollution and Discharge Flux}

To determine the contribution of pollution sources, we applied different wind-driven monsoons with the same tide-generating forces and fixed ammonium concentrations with different river discharges as conditions for a series of model experiments. Subsequent model experiments were designed to determine the amount of ammonium that can be loaded in the harbor, for example, in heavy rainfall situations. Furthermore, we examined differences in the pollutant amount entering the harbor with different discharge fluxes of the NHW river. The river discharge fluxes given from low to high of 10, 50, 100, 200, 300, and $400 \mathrm{~m}^{3} / \mathrm{s}$ were imposed in the model but with the same ammonium concentration for all model experiments. The model results for different river discharges plotted in Figure 16 indicate that almost all ammonium percentages entering the harbor had a slope- 
positive trend, with oscillations in response to the flood-ebb tidal cycles-the ammonium percentage in the harbor increased with time and the increasing flux of the NHW river, except for the $10 \mathrm{~m}^{3} / \mathrm{s}$ flux. Although the river discharge flux exceeded $200 \mathrm{~m}^{3} / \mathrm{s}$, the ammonium percentage entering the harbor was always limited to that of the $200 \mathrm{~m}^{3} / \mathrm{s}$ case and did not increase further (Figure 16). While interpreting the phenomenon of limited ammonium entering the harbor, the ammonium percentage entering the harbor could be restrained by the flow flux through the harbor mouth and by the flux of drawing seawater for cooling through the inlet; however, this needs to be verified.

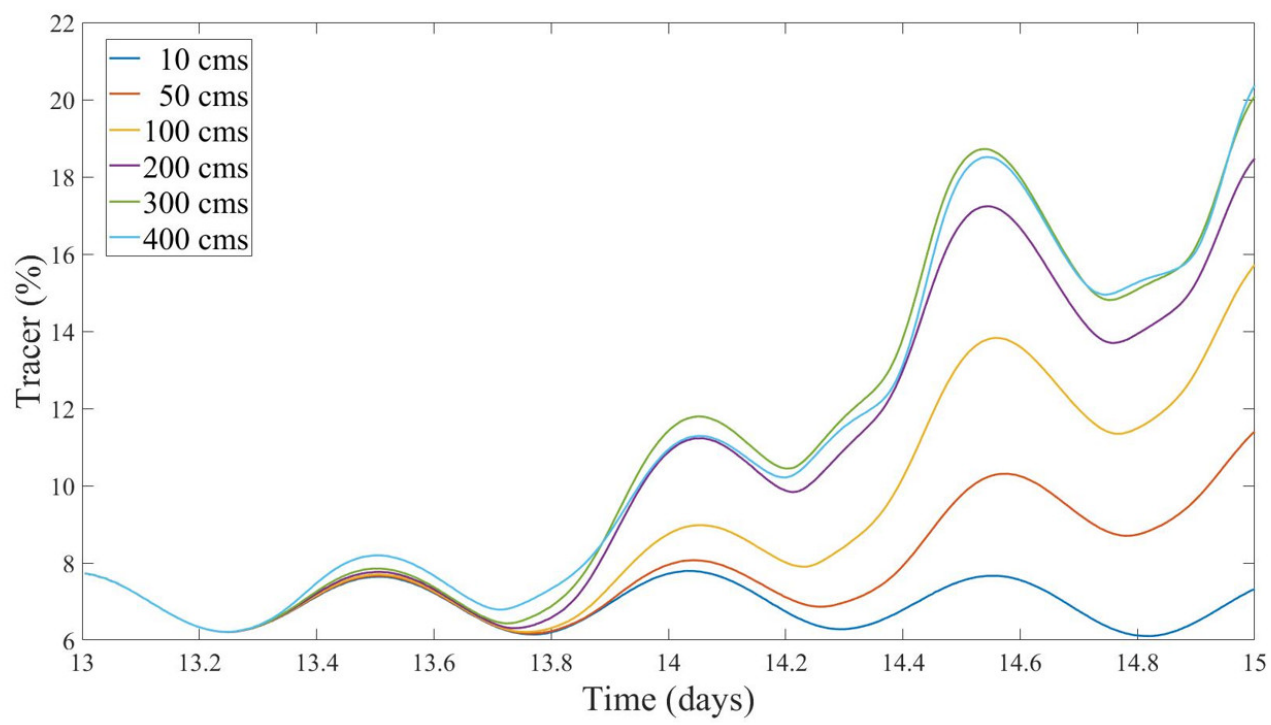

Figure 16. Model results of different river discharges (10-400 $\left.\mathrm{m}^{3} / \mathrm{s}\right)$ show that the percentages of ammonium from the NHW river entering the harbor have a slope-positive trend, with oscillations in response to the flood-ebb tidal cycles-the harbor ammonium percentage increases with time and the increasing flux of the NHW river except for the $10 \mathrm{~m}^{3} / \mathrm{s}$ flux.

\section{Conclusions}

Two pollution sources, namely NHW and CS rivers, were suspected to contaminate the water quality of the MIZ coast, including the MIZ harbor area. Among the two polluting sources, the main source contributing to the contamination of water in the MIZ harbor area remained unclear. To determine the main pollution contributor, the interplay between river-forced, tide-generating, and monsoon-driven water motions in and around the MIZ harbor was examined by performing a series of numerical model experiments. First, to examine the contribution fractions of the two river systems under no-wind conditions, a tracer was released for one river each time during the model runs. The total amount of ammonium entering the harbor from the two river systems was $1.63 \mu \mathrm{M}$ on average, although the amount of ammonium entering varied with the flood-ebb and fortnightly spring-neap cycles. Accordingly, the ammonium concentration of the CS river, obtained by subtracting the concentration of the NHW river from the total average value, was $0.04 \mu \mathrm{M}$, which is less than $2.5 \%$ of that of the NHW river (Figure 13). Thus, the CS river's contribution to the contamination of the water of the MIZ harbor was relatively low; the model results revealed that the NWH river discharge was the primary source contributing to the contamination of water in the MIZ harbor.

Under the effect of northeasterly winds, as observed in winter, monsoon-driven surface currents moved in the alongshore direction and carried the NHW plume and CS plume movements southward while keeping with alongshore currents. An Ekman drift emerging in geostrophic alongshore currents in response to the Earth's rotation pushed the plumes seaward, particularly in the vicinity of the MIZ harbor, although the Earth's rotation effect on the plumes was minor. Irrespective of flood or ebb tidal currents being suppressed by 
strong Asian monsoons, this mechanism avoided contaminating the water quality of the harbor because of the prevalence of northeasterly winds. By contrast, the southwesterly monsoon drove the geostrophic current northward along the coast; concurrently, the coastal sea level increased to form the surface isobar slope up toward the coast, producing a secondary flow to accelerate geostrophic alongshore currents. The northward geostrophic alongshore currents compressed the plumes shoreward due to the Ekman drift acting to the right, forming a relatively narrow-band plume (Figure 15a,b). Irrespective of the flood or ebb tides, the coupling model demonstrated that the southwesterly monsoon-driven current pushed plumes into the harbor favorably along the west pier, but the entering plume distribution inside appeared to be out of phase compared with that outside the harbor. At this point, the model result agreed well with the observed data (Figures 2 and 4). Figure 2 exhibits that the two time series of ammonia concentration variations showed the same tendency, and their peaks usually occurred around the summers of 2010 and 2015. Among seasonal variations, two concentration peaks that could reach $20 \mu \mathrm{M}$ were particularly prominent, indicating that peaks usually appeared in summer and that southwesterly winds prevail at this time. The coupling model results revealed that the water quality of the MIZ harbor was more favorable in winter than in summer. The model results for different river discharges also revealed that almost all ammonium percentages entering the harbor had a slope-positive trend, with oscillations in response to the flood-ebb tidal cycles-the ammonium percentage in the harbor increased with time and the increasing flux of the NHW river, except for the $10 \mathrm{~m}^{3} / \mathrm{s}$ flux. As shown in Figure 16, if the river discharge flux exceeded $200 \mathrm{~m}^{3} / \mathrm{s}$, the ammonium percentage entering the harbor was always limited to that of the $200 \mathrm{~m}^{3} / \mathrm{s}$ case and did not increase further. While interpreting the phenomenon of limited ammonium entering the harbor, the ammonium percentage entering the harbor could be restrained by the flow flux through the harbor mouth and by the flux of drawing seawater for cooling through the inlet.

By performing dimensionless tidal excursion, and Kelvin and Froude number analyses, we found that these magnitude numbers could indicate the importance of tides, winds, and river-forcing on the river plumes. Theoretically, a dimensionless number is used to measure the surface Ekman drift; $\mathrm{Fe}=\mathrm{Ve} / \mathrm{Ci}=0.3 / 0.309 \approx 1$ shows that the wind-driven surface drift competes with the river-forced plume motion in this case. The NHW estuary-shelf system estimated from some observed data appears not to be a large-scale type $(\mathrm{Fe} \approx 1$; $\mathrm{K}<<1 ; \mathrm{P}<<1$ ). Overall, these numbers indicate that tidal currents violently compete with Asian monsoons to determine the river-forced plume fate of the NHW river. The effect of the harbor mouth's width and the drawing water flux for FPC system cooling was beyond the scope of the present study, but our efforts are still ongoing.

Author Contributions: Conceptualization, C.-Y.H. and H.-J.L.; methodology, H.-J.L. and C.-Y.H.; software, C.-Y.H.; validation, H.-J.L., C.-H.W. and T.-H.F.; formal analysis, T.-H.F. and C.-H.W.; investigation, C.-Y.H., H.-J.L. and T.-H.F.; writing—review and editing, H.-J.L. All authors have read and agreed to the published version of the manuscript.

Funding: The article processing charge was funded by the Ministry of Science and Technology (Taiwan) under grant MOST 110-2611-M-019-010.

Institutional Review Board Statement: Not applicable.

Informed Consent Statement: Not applicable. 
Data Availability Statement: The topographic and hydrological observed data that support the findings of this study are openly available in the ODB of the Ministry of Science and Technology, Taiwan at https:/ / www.odb.ntu.edu.tw/en/ (accessed on 16 January 2020). The ADCP and sealevel height data that support the findings of this study are available on request from the FPC at https://www.fpg.com.tw/tw (accessed on 16 January 2020). Derived data of the CS and NHW discharge fluxes that support the study are available from Water Resources Department of the Ministry of Economic Affairs and Forestry Bureau, Council of Agriculture at https://gweb.wra. gov.tw/hydroinfo/ (accessed on 28 April 2020) and https:/ / conservation.forest.gov.tw/0002026 (accessed on 28 April 2020), respectively. The water quality data supporting the findings of this study are available from the corresponding author on request.

Acknowledgments: Authors C.-Y.H., T.-H.F. and H.-J.L. were supported by the Formosa Petrochemical Corporation. The authors C.-H.W. and H.-J.L. would like to thank all colleagues who contributed to this study. Authors C.-Y.H. and H.-J.L. thank Shih-Yan Dai for his help with the fieldwork and provision of valuable materials.

Conflicts of Interest: The authors declare no conflict of interest.

\section{References}

1. Wessel, P.; Luis, J.F.; Uieda, L.; Scharroo, R.; Wobbe, F.; Smith, W.H.F.; Tian, D. The Generic Mapping Tools version 6. Geochem. Geophys. Geosyst. 2019, 20, 5556-5564. [CrossRef]

2. Wessel, P.; Smith, W.H.F. New, improved version of Generic Mapping Tools released. EOS Trans. AGU 1998, 79, 579. [CrossRef]

3. Liou, S.M.; Lo, S.L.; Wang, S.H. A Generalized Water Quality Index for Taiwan. Environ. Monit. Assess. 2004, 96, 35-52. [CrossRef] [PubMed]

4. Lee, H.J.; Meng, P.J.; Chen, C.C.; Tew, K.S. Monsoon effects on the residence time of a coastal lagoon in southwestern Taiwan Estuar. Coast. Shelf Sci. 2020, 233, 106535. [CrossRef]

5. Putri, M.S.A.; Lou, C.H.; Syai'in, M.; Ou, S.H.; Wang, Y.C. Long-Term River Water Quality Trends and Pollution Source Apportionment in Taiwan. Water 2018, 10, 1394. [CrossRef]

6. Fang, T.H.; Chen, J.L.; Huh, C.A. Sedimentary phosphorus species and sedimentation flux in the East China Sea. Cont. Shelf Res. 2007, 27, 1465-1476. [CrossRef]

7. Chao, S.Y. Tidal modulation of estuarine plumes. J. Phys. Oceanogr. 1990, 20, 1115-1123. [CrossRef]

8. Lin, C.T.; Fan, K.L.; Chao, S.Y. Small-scale plumes from a semi-enclosed basin: Yin-Yang bay. Terr. Atmos. Ocean. Sci. 1994, 5, 91-107. [CrossRef]

9. Lin, C.T.; Chao, S.Y.; Fan, K.L. Wind modulation of small-scale plumes from Yin-Yang bay. Terr. Atmos. Ocean. Sci. 1995, 6, 621-639. [CrossRef]

10. Eisma, D. Intertidal Deposits: River Mouths, Tidal Flats, and Coastal Lagoons; CRC Press: Boca Raton, FL, USA, $1998 ;$ p. 525.

11. Lee, H.J.; Chao, S.Y. A climatological description of circulation in and around the East China Sea. Deep-Sea Res. II 2003, 50, 1065-1084. [CrossRef]

12. Lee, H.J.; Chao, S.Y.; Liu, K.K. Effects of Reduced Yangtze River Discharge on the Circulation of Surrounding Seas. Terr. Atmos. Ocean. Sci. 2004, 15, 111-132. [CrossRef]

13. Semtner, A.J. An oceanic general circulation model with bottom topography. Numer. Simul. Weather Clim. Tech. Rep. 1974, 9, 99.

14. Lee, H.J.; Chao, S.Y.; Fan, K.L. Flood-Ebb disparity of tidally Induced recirculation eddies in a semi-enclosed basin: Nan Wan Bay. Cont. Shelf Res. 1999, 19, 871-890. [CrossRef]

15. Lee, H.J.; Chao, S.Y.; Liu, K.K.; Huang, S.J.; Gong, G.C. Tidal effects on circulation in and near the East China Sea. Terr. Atmos. Ocean. Sci. 2014, 25, 233-254. [CrossRef]

16. Chao, S.Y.; Paluszkiewicz, T. The hydraulics of density currents over estuarine sills. J. Geophys. Res. 1991, 96, 7065-7076. [CrossRef]

17. Chao, S.Y.; Shaw, P.-T.; Wu, S.Y. El Nio modulation of the South China Sea circulation. Prog. Oceanogr. 1996, 38, 51-93. [CrossRef]

18. Pacanowski, R.C.; Philander, S.G.H. Parameterization of vertical mixing in numerical models of tropical ocean. J. Phys. Oceanogr. 1981, 11, 1443-1451. [CrossRef]

19. Sarmiento, J.L.; Bryan, K. An ocean transport model for the North Atlantic. J. Geophys. Res. 1982, 87, 394-408. [CrossRef]

20. Foreman, M.G.G. Manual for Tidal Heights Analysis and Prediction; Institute of Ocean Sciences: Patricia Bay, BC, Canada, 1997; p. 110.

21. Pugh, D. Tides, Surges and Mean Sea Level: A Handbook for Engineers and Scientists; John Wiley \& Sons: Chichester, UK, 1987; 472p.

22. Simons, T.J. Verification of numerical models of Lake Ontario: Part I. Circulation in spring and early summer. J. Phys. Oceanogr. 1974, 4, 507-523. [CrossRef] 